\title{
OVER DE ENTOMOLOGIE, HET HOGER ONDERWIJS EN ENIGE VERWANTE ZAKEN
}

DOOR

\author{
DR. S. LEEFMANS
}

Deze bescheiden bijdrage aan de bundel bij het afscheid van de hoogleraren L. F. DE Beaufort en J. W. E. IhLE, schrijf ik met een oprecht gevoel van leedwezen, want hun nuttige openbare, of ficiële werkzaamheid ten bate van de Zoölogische wetenschap neemt een einde, gelukkig op normale wijze, wegens het bereiken van de gestelde leeftijd voor een otium cum dignitate.

Moge hun een hoge leeftijd in gezondheid van lichaam en geest beschoren zijn, want dat hun wetenschappelijke werkzaamheid nu zal eindigen, gelooft wel niemand, die hen kent!

Het is zeker in hun geest, dat ik hier - zij het zeer beknopt - onderwerpen behandel, waarin zij in de eerste plaats belang zullen stellen, rakende zowel hun geliefde zoölogie, als het Hoger Onderwijs, dat zij op zo wel prominente als eervolle wijze hebben gediend.

Uiteraard bepaal ik mij nu verder tot de Entomologie.

Reeds onze Gouden Eeuw bracht ten onzent grote figuren voort, als SwamMERDAM en LyONET, voortreffelijke insectenanatomen en biologen uit de eerste periode, maar ook biologen als Goedaert, Merian, de GeER, elders Rösel v. RosenhoFf.

Treffend is uit die tijd de hoge mentaliteit, de enthousiaste bewondering voor de zesvoeters, afspiegelend de grootheid der Natuur, in hun schitterende kleuren, fraaie vormen en wonderlijke levenswijzen. Men denke aan SEPP en Merian. Geen spoor van enige utiliteitsgedachte is nog in hun werken te vinden. Het insect is voor hen een openbaring Gods, schoon van vorm en kleur, doelmatig in zijn levensuitingen, een afspiegeling van de wijze scheppingskracht Gods, in overeenstemming met de streng religieuze opvattingen van die tijd.

Later, in de achttiende- en negentiende eeuw trad de descriptieve zijde in de Entomologie meer op de voorgrond; de honderdduizenden soorten dienden te wonden benoemd, ingedeeld en gerangschikt en daarvoor was ook de morphologie onmisbaar. 
Het was de periode der grote insecten-systematici, LINNÉ in de eerste plaats, verder Fabricius, Latreille, Degeer, Herbst, Panzer, Scopoli, von Paykull, Olivier, von Motschulski, Wesmael, Westwood, Stainton, Zeller, Ratzeburg, Smith, von Schrank, Hagen, enz. enz. Een rij van grote stichters en oprichters der systematische entomologische wetenschap.

Vele amateurs namen ook aan de opbouw deel, zowel wat de systematiek als wat de biologie betreft en nog altijd weerspiegelen de ledenlijsten der Ned. Entomologische Vereniging als die der Verenigingen in het Buitenland de grote belangstelling van deze gewaardeerde „niet-vaklieden” voor de Entomologische Wetenschap.

Zijn niet bijna alle samenvattende oudere systematische handboeken hier te lande en vaak ook elders, door liefhebbers geschreven, ,liefhebbers". stellig van een formaat van de huidige vaklieden; ik noem slechts SNELLEN VAN Vollenhoven, v. D. Wulp, Snellen en ook Everts (de H.B.S.-Leraar), wijlen Uyttenbogaart (de jurist), onze erevoorzitter Mc. Gillavry en Willemse (de chirurg en de arts), wijlen Reclaire (de chemicus), Corporaal (tabaksen theeplanter), v. D. Wielen (ondernemer), PolAK en LempKe, onderwijzers, enz. enz. en verder zijn vogels van de meest verschillende pluimage enthousiaste leden der Entomologische Vereniging, van kantoorbedienden tot profs bij de Waterstaat.

Tot voor kort waren de meeste „specialisten” in ons land particuliere ,amateurs".

Het is niet veel meer dan een zestigtal jaren geleden, dat hier te lande of ficiële zoölogen hun aandacht meer gingen besteden aan de insecten.

J. Th. Oudemans, de schrijver van het nog steeds onovertroffen handboek voor de Nederl.' Insecten, J. Ritsema Bos (was meer algemeen landbouwzoöloog), Docters van Leeuwen en - last not least - wijlen de Meyere.

Zij hebben er zeer veel toe bijgedragen, dat hier te lande aan de entomologie in de officiële zoölogie op de duur de aandacht werd gegeven, die haar toekomt.

Nadien werden de insecten hier te lande ook meer en meer betrokken in anatomisch, histologisch, e.a. algemeen zoölogisch en biologisch onderzoek.

Elders, in grote landen, als Amerika, Engeland, Duitsland, Frankrijk enz. was dat al eerder geschied.

Vooral na I9Io kwam een andere, de practische zijde der Entomologie in Europa tot grotere ontwikkeling, waarin de Verenigde Staten reeds waren voorgegaan.

De toegepaste entomologie, voordien in Europa min of meer "gesmoord" in de phytopathologie, kwam haast sprongsgewijs in Europa en de koloniale bezittingen tot grote bloei.

Aanleiding hiertoe was in Europa vooral de reis van Escherich e.a. naar de Verenigde Staten. Daar was de toegepaste zijde der entomologie veel verder 
gevorderd dan in Europa, omdat het klimaat daar in de zomer in 't algemeen veel gunstiger voor het insectenleven is dan in Europa, de monocultures daar zeer uitgebreid zijn en men er bovendien in hevige mate, zowel in de bosbouw (Plakker en Basterdsatijnvlinder), de fruitteelt (Carpocapsa, Japanse kever), de graanbouw (Hessische mug), de Citrus-cultuur (Schildluizen) en de katoenteelt enz. te kampen had gekregen met van elders (Europa, Azië, Z.-Amerika) ingevoerde plagen, die enorme schade aanrichtten.

In Europa werd na 1920 veel physiologisch onderzoek gedaan (ademhaling, stofwisseling) en ecologisch onderzoek (invloed van temperatuur en vochtigheid, vooral epidemiologie) en wat de wetenschappelijke grondslagen aangaat kwam Europa snel voor. Dat werd echter weldra in de U.S.A. opgemerkt en ingehaald.

Wat „biologische bestrijding” aangaat, was Amerika weer vóór (parasieteninvoer tegen ingevoende plagen in Californië, N.O. Amerika en Hawaii). Later heeft ook Engeland in zijn Dominions (in Azië, Afrika en Amerika) en ook Nederland, in zijn koloniën, deze methode toegepast en in verschillende gevallen met succes.

In Holland waren wij omstreeks I935, wat oorspronkelijk onderzoek betreft, achter bij onze Oostelijke buren. Nadien heeft zich dat vooral sterker ontwikkeld op het gebied van de Bosbouw en Tuinbouw. Het onderzoek in de bosbouw ging vooral in de richting van ecologisch onderzoek, dat in de tuinbouw omvat zowel biologie als bestrijding van insectenplagen in boomgaarden, in de groenteteelt en in de kascultures.

Het onderzoek in de tuinbouw is vooral vruchtbaar gebleken, door het consequenter rekening houden met de phaenologie der schadelijke soorten, en door het bestuderen der biologie onder onze zeer bijzondere klimaatsomstandigheden, in ons uiterst labiel littoraal klimaat.

Voor de Bosbouw (Mariëndaal, Oosterbeek) waren in 19454 biologen werkzaam, voor de tuinbouw 7 entomologen, welke laatsten verdeeld zijn over 5 locale stations.

$\mathrm{Na}$ de tweede wereldoorlog voltrokken zich in de toegepaste entomologie in land-, tuin- en bosbouw enorme veranderingen door het beschikbaar komen van de nieuwe, zeer krachtig werkende insecticiden.

Dit waren gedeeltelijk Europese vondsten $D D T$ (Zwitserland), $\mathrm{HCH}$ (Frankrijk en Engeland), E 605 (Thiophos, Parathion) uit Duitsland, HETP, $T E P P$ (Bladan, Mortopal) (Duitsland), gedeeltelijk ook Amerikaanse vindingen zoals Azobenzeen, DDD (Rothane) de Methoxy-analoog van DDT, Thanite, Piperonyl butoxide, Chlordane of Octachlor, Toxaphene en de interne therapie middels natrium selenaat.

Vooral de cursief gedrukte hebben een ware revolutie veroorzaakt. Ze bleken veel werkzamer dan de tot dusverre bekende insectendodende middelen, maar zijn ook meest veel giftiger dan de andere midelen en leveren daandoor ook veel meer gevaar op voor de gebruiker en de consument. Zodoende brengen zij ook nieuwe problemen mede, die oplossing vereisen. 
Verschillende dezer middelen werken namelijk veel langer dan de oudere en sommige worden ook door de planten onveranderd opgenomen.

Het veelgebruikte DDT veroorzaakt, indien toegepast tegen een bepaalde plaag (bv. Carpocapsa $=$ de Appelmot) sterke vermeerdering van andere plagen als b.v. spintmijten (Tetranychus) en bladluizen.

DDT blijkt bij toepassing op fourage-gewassen of tegen ecto-parasieten op vee een residu achter te laten, dat bij opname bij warmbloedigen in het vetweefsel en andere organen wordt opgenomen en slechts zeer langzaam wordt uitgescheiden. In melk en de producten daarvan van zulke zoogdieren blijkt dan de DDT in voldoende hoeveelheden te kunnen voorkomen om zogende, jonge dieren te schaden (ook andere nieuwe middelen werken langdurig).

De opname van sommige nieuwe middelen door de planten brengt eveneens gevaren mede voor de consument.

De nieuwe middelen zijn zo effectief, dat ze ook parasieten en predatoren van schadelijke soorten doden en dus evenwichtstoringen in een biocoenose kunnen teweeg brengen. Dit is echter vooral van belang voor bossen en natuurlijke milieus, niet in onze, ,voedselfabrieken" in de land- en tuinbouw.

Verder maakt men zich ongerust over het goed vastgestelde feit, dat - gelukkig nog maar in enkele gevallen - bij insecten resistentie tegen bepaalde insecticiden is gebleken.

Bezien we nu het vorenstaande eens in vérband met het hoger onderwijs.

Ondanks de erkenning van het grote belang voor onze agrarische productie van de landbouw-entomologie en van de medische en veterinaire entomologie voor gezondheid van mens en vee, is er hier te lande slechts één hoogleraar voor entomologie (te Wageningen). Te Leiden zal nu een conservator toegepaste entomologie gaan doceren, tot dusverre geschiedde dit door een hoogleraar voor zoö.'ogie. Te Utrecht doceert Dr. J. B. KRIJgSman toegepaste entomologie, te Groningen bestaat er een hiaat ten dezen. Te Amsterdam doceert een lector toegepaste entomologie en een conservator algemene entomologie.

De vraag mag nu gesteld: acht men de entomo!ogie nog niet belangrijk genoeg voor de gemeenschap? Is één hoogleraar in dit zowel theoretisch als practisch zo belangrijke vak voor het gehele land adequaat met zijn belangrijkheid? Komt behalve te Wageningen en Amsterdam de specifiek entomologische kant wel tot zijn recht? M.i. niet en vooral niet in deze tijd, waar enerzijds door de nieuwe middelen nieuwe problemen oprijzen, waardoor fundamentele vragen om oplossing vragen wil men niet vastlopen.

Schijnbaar schijnt het zwaartepunt voor de bestrijding naar de chemische kant te zijn verplaatst, maar in werkelijkheid is deze zijde weer zeer afhankelijk van de dier- en plant-physioloog en de levenswijze der insecten blijft bovendien een onmisbare basis. Ook soortenkennis kan niet worden gemist!

Alleen door samenwerking van de entomoloog-bioloog, de physioloog en de chemicus kunnen de problemen, waarop men nu is gestuit en die ik hiervoor heb aangegeven, worden opgelost. 
Ook is dat het geval indien men tracht tegen bepaalde insecten resistente cultuurplanten te vinden. Een dergelijk onderzoek in zake de Coloradokever is reeds in gang en daarbij werken samen: de practijk, een botanisch-physioloog, een entomoloog, physiologen en chemici.

Evenzo is de ecologische kant nog steeds belangrijk, vooral in bos en heide, makar hieraan wordt in ons land reeds een 12-tal jaren energiek gewerkt (Voûte en medewerkers).

Cultuurmethoden zijn het belangrijkst in de landbouw (akkerbouw), waar men veel kan bereiken door wisselbouw, iets dat in onże tuinbouw door de kleine oppervlakten gecn of weinig effect heeft.

Zo blijven ook de andere dan chemische bestrijdingsmethoden van veel belang.

De vraag zal nu worden gesteld: is er voor biologen-entomologen plats in ons land en in Indonesië?

Daarop kan geantwoord worden, dat in ons land er nog steeds een tekort aan entomologisch opgeleide biologen bestaat en er is veel vraag naar deze categorie, omdat ook de fabrikanten van insecticiden en zelfs handelsfirma's ze nodig hebben, een groot verschil met vroeger.

Indonesië heeft bepaald groot gebrek aan entomologisch opgeleide biologen en bovendien is er vraag vanuit slechts nog kort autonome landen als India, Pakistan, de Arabische landen, Afrika.

Maar ook entomologen-systematici zijn in veel te gering aantal in ons land aan onze Musea aanwezig. Gelegenheid tot opleiding dezer wetenschappelijk en practisch onmisbare categorie is er bij ons slechts aan enkele Universiteiten aanwezig.

Tot voor kort was het voor particulieren nog mogelijk standaardcollecties bijeen te brengen en een belangrijke rol te vervullen bij het benoemen of beschrijven van insecten. Dat wordt onder de huidige, zozeer gewijzigde omstandigheden, hoe langer hoe moeilijker; noem ik het probleem van voldoende droog houden der collectie in particuliere woningen, de kostbare berging, de dure literatuur en de nog kostbaander optische hulpmiddelen. En waar zijn de onafhankelijk welgestelden van vroeger gebleven, die de tijd ervoor ter beschikking hebben? Ook hierin moet van Staatswege dus beter worden voorzien.

Er blijft dus zowel wat Onderwijs als Museum-krachten betreft ten behoeve der Entomologie hier te lande eveneens heel wat te wensen over. Laten wij hopen, dat de gebleken practische betekenis der Entomologie voor onze samenleving, het belang van de successievelijke voorziening der desiderata moge doen beseffen, bij hen, die hierop invloed kunnen uitoefenen.

Gaf ik aan het begin van deze schets een vluchtige historische impressie van het wezen der entomologie in onze Gouden Eeuw, dan was dit om te doen uitkomen, dat in dien tijd de entomologie was een „scientia amabilis”. Dat is zij voor de adepten natuurlijk nog, maar de bedoeling was vooral te laten uitkomen, dat zij sindsdien ook in hoge mate geworden is : een "scientia utilis". 